\title{
Marketed as Bulk Active Ingredient
}

National Cancer Institute

\section{Source}

National Cancer Institute. Marketed as Bulk Active Ingredient. NCI Thesaurus. Code C73586.

A category specifying that a product is marketed as a bulk active ing redient. 